ARAŞTIRMA MAKALESI

\title{
Evaluation of the Clinical Effects of Insomnia and Excessive Daytime Sleepiness in Older Adults
}

\author{
(iD Saadet KOÇ OKUDUR ${ }^{1}$, (D) Pınar SOYSAL ${ }^{2}$, (i) Lee SMITH ${ }^{3}$, (iD Burcu AKPINAR SÖYLEMEZ ${ }^{4}$, (id) Merve Aliye \\ $\mathrm{AKYOL}^{4}$
}

\footnotetext{
${ }^{1}$ Manisa State Hospital, Department of Geriatric Medicine, Manisa, Turkey

2 Bezmialem Vakif University, Department of Geriatric Medicine, Faculty of Medicine, Istanbul, Turkey

${ }^{3}$ Anglia Ruskin University, The Cambridge Centre for Sport and Exercise Sciences, Cambridge, United Kingdom

${ }^{4}$ Dokuz Eylul University, Faculty of Nursing, Department of Internal Medicine Nursing, Inciralti, Izmir
}

\begin{abstract}
Background: Insomnia and excessive daytime sleepiness (EDS) are common sleep disorders in older adults. Both are associated with numerous adverse health conditions. Objectives: The aim of our study is to evaluate the effects of insomnia and/or EDS on functionality, gaitbalance functions, cognition, mood, falls and fear of falling (FoF) in older adults, to determine its importance in terms of nursing practice and to raise awareness on the subject. Methods: A cross-sectional study design was used. A total of 661 outpatients were included, aged $\geq 65$ years. All patients underwent comprehensive geriatric assessment. Comorbidities, falls in the last year and drugs used were recorded. The Falls Efficacy Scale-International (FES-I) was used to determine and classify FoF, Mini-Mental State Exam (MMSE) for neurocognitive evaluation, and Basic Activities of Daily Living Scale (BADL) and Instrumental Activities of Daily Living (IADL) scales were used to evaluate activities of daily living. Insomnia Severity Index (ISI) with scores of $\geq 8$ points indicated insomnia, and the Epworth Sleepiness Scale score of $\geq 11$ points indicated EDS. Results: The mean age was $77.78 \pm 7.73$ years. The prevalences of EDS, insomnia, and EDS and insomnia were $5.45 \%$, $50.38 \%$, and $12.56 \%$, respectively. As a result of bivariate and multivariate logistic regression analysis, there was a significant relationship between EDS and insomnia with moderate and high FoF (OR=2.24, 95\% CI: 1.74 to 2.89), polypharmacy (OR=1.20, $95 \%$ CI: 1.09 to 1.30$)$, BADL (OR=0.94, 95\% CI: 0.93 to 0.96), IADL (OR=0.87, 95\% CI: 0.84 to 0.91 ) and MMSE (OR=0.91, 95\% CI: 0.86 to 0.98$)$ (p<.05). Conclusions: There is a close relationship between EDS and insomnia and FoF, polypharmacy, activities of daily living and cognition in older adults. It can be recommended that healthcare professionals who are working with older adults, should consider these parameters when evaluating the area of sleeping.
\end{abstract}

Keywords: Insomnia, Excessive Daytime Sleepiness, Older Adults

\section{$\ddot{O ̈ z}$}

\section{Yaşı Bireylerde Uykusuzluk ve Gündüz Aşırı Uykululuk Halinin Klinik Etkilerinin Değerlendirilmesi}

Giriş: Uykusuzluk ve gündüz aşırı uykululuk (GAU), yaşlı hastalarda sık görülen uyku bozukluklarındandır. Her ikisi de çok sayıda olumsuz sağlık durumlarıyla ilişkilidir. Amaç: Uykusuzluk ve/veya GAU'nun yaşlılarda fonksiyonellik, yürüme-denge fonksiyonları, kognisyon, duygu durum, düşme ve düşme korkusu (DK) üzerine etkilerini değerlendirmek, hemşirelik pratiği açısından önemini belirlemek ve konuyla ilgili farkındalık yaratmaktır. Yöntem: Kesitsel araştırma tasarımı kullanıldı. Çalışmaya $\geq 65$ yaş, 661 ayaktan hasta dahil edildi. Tüm hastalara ayrıntılı geriatrik değerlendirme yapıldı. Komorbiditeler, son bir yıldaki düşmeler ve kullanılan ilaçlar kaydedildi. DK' nu belirlemek ve sınıflandırmak için Uluslararası Düşme Etkinliği Ölçeği (UDEÖ), nörokognitif değerlendirme için Standardize Mini Mental Test (SMMT) ölçeği, günlük yaşam aktivitelerini değerlendirmek için Temel Günlük Yaşam Aktiviteleri (TGYA) ve Enstrümental Günlük Yaşam Aktiviteleri (EGYA) kullanılmıştır. Uykusuzluk Şiddet İndeksinin $\geq 8$ puan olması uykusuzluk, Epworth Uykululuk Skalasının $\geq 11$ puan olması GAU olarak değerlendirildi. Bulgular: Yaş ortalaması $77.78 \pm 7.73$ yıldı. GAU, uykusuzluk ve GAU ve uykusuzluk halinin prevalansları sırasıyla $\% 5.45, \% 50.38$ ve \%12.56 idi. İki değişkenli ve çok değișkenli lojistik regresyon analizi sonucunda; GAU ve uykusuzluk ile orta ve yüksek DK (OR=2.24, \%95 CI: 1.74-2.89), polifarmasi (OR=1.20, \%95 CI: 1.09-1.30), TGYA (OR=0.94, \%95 CI: 0.93-0.96), EGYA (OR=0.87, \%95 CI: 0.84-0.91) ve SMMT (OR=0.91, \%95 CI: 0.86-0.98) arasında anlamlı ilişki saptanmıştır ( $<<.05)$. Sonuç: Yaşlı yetişkinlerde GAU ve uykusuzluk ile DK, polifarmasi, günlük yaşam aktiviteleri ve kognisyon arasında yakın ilişki vardır. Yaşlı bireylerle çalışan sağlık çalışanlarının uyku alanını değerlendirirken bu parametreleri göz önünde bulundurmaları önerilmektedir.

Anahtar Kelimeler: Uykusuzluk, Gündüz Aşırı Uykululuk, Yaşı Birey

Geliş Tarihi / Received: 10.07.2021 Kabul Tarihi / Accepted: 05.10.2021

Correspondence Author: Associate Professor, Bezmialem Vakif University, Department of Geriatric Medicine, Faculty of Medicine, Istanbul, Turkey. Telefon: +90533-612-40-66 E-posta: dr.pinarsoysal@ hotmail.com

Cite This Article: Koç Okudur S, Sosyal P, Smıth L, Akpınar Söylemez B, Akyol M A, Evaluation of the Clinical Effects of Insomnia and Excessive Daytime Sleepiness in Older Adults. Dokuz Eylül Üniversitesi Hemşirelik Fakültesi Elektronik Dergisi. 2021; 14(4): 433- 441 
$\mathbf{S}$

leep complaints are common, reported by more than half of older adults (1), insomnia and excessive daytime sleepiness (EDS) are particularly prominent (2). Insomnia is characterized by difficulty initiating or maintaining sleep, feeling restless after sleeping for a sufficient amount of time, and waking up early in the morning and not being able to go back to sleep (3). Insomnia is observed in more than $50 \%$ of individuals aged 65 and over, and between $45 \%$ and $75 \%$ in older adults living in nursing homes (4). EDS is defined as the state of sleepiness during the day when the individual should be active and awake (2). EDS is closely associated with age-related changes, changes in circadian rhythm, sleep pattern disorder, insomnia, medications, lifestyle factors, psychological disorders, and medical illnesses (5). However, the risk factors are still not fully known.

Insomnia and EDS are associated with numerous adverse health conditions, some of which include cognitive impairment, depression, falls, cardiovascular diseases, and decreased quality of life in older adults (6-8). However, healthcare professionals, including nurses, may tend to view sleep disturbances as a normal part of aging (3). This misperception may prevent proper assessment of sleep problems and initiation of appropriate treatment. In recent years, studies on the approach to geriatric syndromes such as dementia, malnutrition and falls have been increasing in nursing practice (9-11). However, the number of studies examining the importance of sleep disorders in nursing practice is still limited. For example, in a study evaluating the frequency of falls and risk factors in elderly individuals living in the community, insomnia was identified as a risk factor for falling (12). In another study, the clinical, physical and mental health conditions of patients with advanced heart failure were evaluated and it was shown that sleep apnea and EDS were associated with the adverse health conditions of the patients (13). As far as we know, there are no studies to evaluate the risk factors of insomnia and EDS, which can often be related to each other, separately or together, and the clinical consequences of these two conditions in terms of falling, fear of falling, cognitive impairment and depression, which are very important in geriatric practice. Therefore, the aim of this study is to evaluate the effects of insomnia and/or EDS on functionality, gait-balance functions, cognition, mood, fear of falling and falling in older adults, and to determine its importance in terms of nursing practice and to raise awareness on the subject.

\section{Type of Research}

\section{Methods}

This was a descriptive and cross-sectional study.

\section{Place and Time of Study}

This study involved 955 outpatient clinic patients aged 65 years who were admitted to one geriatric clinic between January 2020 and February 2021 in Turkey.

\section{Population and Sampling}

All the patients underwent comprehensive geriatric assessment (14). Patients who had severe illness that may impair their general health status, such as acute cerebrovascular event, sepsis, acute renal failure, and acute respiratory failure; patients who declined to participate; those who take medication for sleep disorders were excluded. Patients with dementia or those who have severe vision and hearing impairment that prevent communication and understanding commands during the examination were also excluded. After exclusion of patients who did not meet the inclusion criteria, the data of the remaining 661 patients were evaluated retrospectively.

\section{Data Collection Tools}

Age, gender, education, marital and living status, number of medications, number of falls in a year, comorbid diseases (hypertension, diabetes mellitus, chronic obstructive pulmonary disease [COPD], congestive heart disease, osteoarthritis, ischemic heart disease, cerebrovasculer events, peripheral artery disease, Parkinson's Disease) were recorded.

Falls

Falls were confirmed if the patient had fallen in the previous year except for tripping on a rug and slipping on wet floor. Gait and balance functions were evaluated with Tinetti scoring (15).

\section{Polypharmacy}

Polypharmacy was confirmed as concurrent use of more than four drugs (14).

Fear of Falling

The Falls Efficacy Scale-International (FES-I) was used to determine and classify fear of falling (FoF). Total FES-I scores range from minimum 16 (no concern about falling) to maximum 64 (severe concern about falling). In addition, if the total score of the FES-I scale was 16-19, 20-27 and $\geq 28$, it was assumed that there was low, moderate, and high concern about falling, respectively $(16,17)$.

Postural Instability

A medical professional stood behind the patient, the patients shoulders were pulled towards him/her quickly and vigorously, with a move strong enough to displace the center of gravity, causing the patient to take a step backwards. The number of steps taken back or falling was examined. Postural instability finding was accepted as positive (+) if the patient fell when the examiner did not catch him/her or the patient tended to lose his/her balance even with a small touch on the shoulders (18).

\section{Cognitive Evaluation}

MMSE was applied to all patients for neurocognitive evaluation. A geriatrician interviewed the informants of each participant to obtain information on course of participant's cognitive functioning and activities of daily living over the past years, and neurocognitive assessment was carried out on participants who may have cognitive impairment. Dementia patients were excluded from the study.

Emotional Status Evaluation 
Functional Status Evaluation

Activities of daily living were assessed by Basic Activities of Daily Living Scale (BADL) and Instrumental Activities of Daily Living (IADL) scales (14).

Insomnia Evaluation

The Insomnia Severity Index (ISI) consists of 7 questionnaire items that capture self-reported symptoms and daytime consequences of insomnia, according to criteria from the Diagnostic and Statistical Manual of Mental Disorders, Fourth Edition. ISI scores range from 0 to 28 , with higher scores indicating more severe insomnia. ISI scores of 8 or higher indicated insomnia $(20,21)$.

Excessive Daytime Sleepiness (EDS) Evaluation

EDS was assessed using the Epworth Sleepiness Scale (ESS). The ESS is a 4-point Likert-style questionnaire composed of eight items, in which the subject marks the possibility of taking a nap in routine situations such as watching TV, lying down to rest, and being a passenger in a vehicle. The scoring for each item varies from 0 (no chance of napping) to 3 (great probability of napping). Total score is based on a scale of 0 to 24 . A score of $\geq 11$ points indicates EDS. The ESS has a high sensitivity (93.5\%) and high specificity (100\%) with a cut-off score of $\geq 11$ for an abnormal level of daytime sleepiness (22).

\section{Data Analysis}

Data were analyzed using SPSS, version 22. Descriptive statistics for patients' characteristics and pre-existing chronic disease conditions were calculated in the overall population. The entire study group was evaluated in four groups: control group without insomnia and/or EDS, only the EDS group, only the insomnia group, and the EDS and insomnia group. Mean and standard deviation were summarized and compared using t-test for age, and proportions were summarized and compared using chi square tests for the rest of the categorical variables. Univariate, age-adjusted and genderadjusted regressions were carried out to examine the association using logic regression (OR and 95\% CI) for other outcomes. The sample size needed was calculated to be 278 patients with an acceptable error of $5 \%$ and a $95 \%$ confidence level.

\section{Ethical Considerations}

Informed consent was provided by each participant or a legal guardian before participating in the study. Ethics in Research Committee of the local ethics committees approved this study (Approval number: 2019/362, Date: 8.5.2019). Research and publication ethics were followed in this study.

\section{Results}

The mean age of the 661 outpatients in the sample was $77.78 \pm 7.73$ years $(73.13 \%$ of them female), and the mean education level was $4.94 \pm 4.94$ years. The prevalence of EDS, insomnia and the combined prevalence of EDS and insomnia were $5.45 \%, 50.38 \%$, and $12.56 \%$ respectively. The prevalences in patients aged 60-70 years, 70-80 years, and $>80$ years are shown in Figure 1.

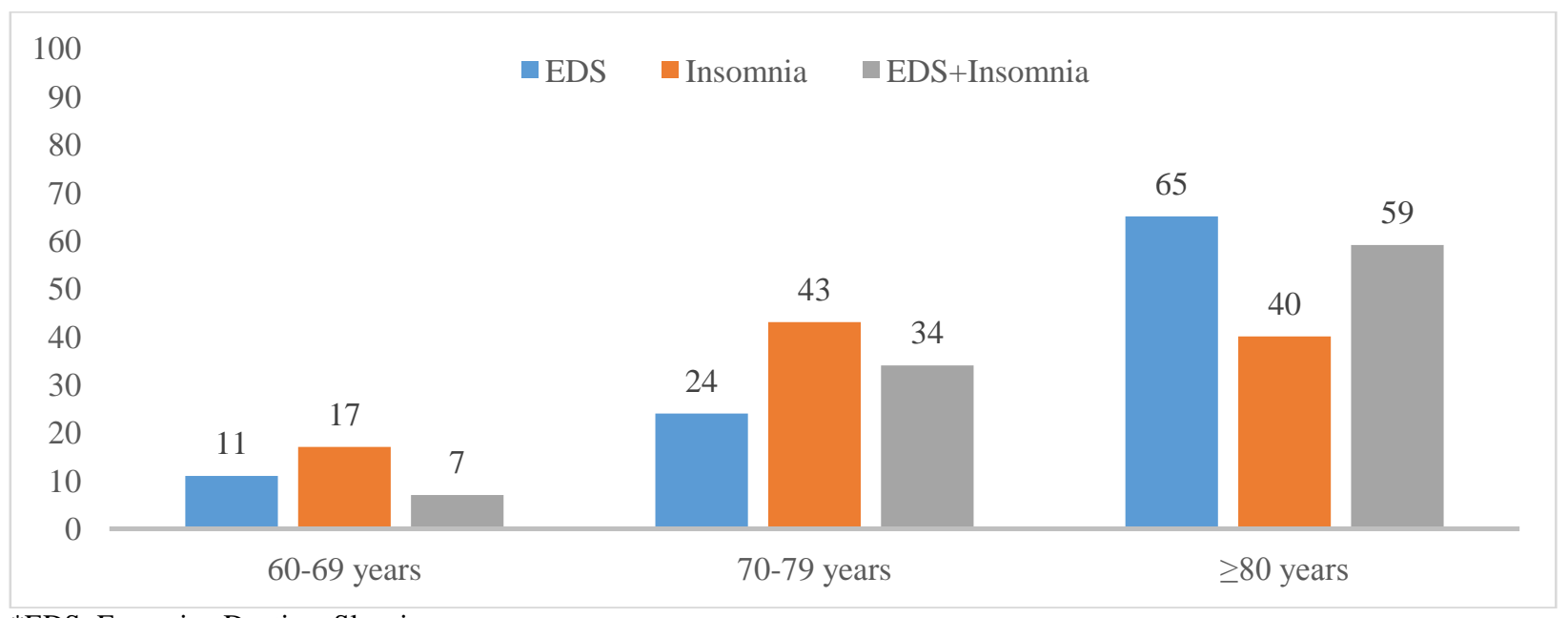

*EDS: Excessive Daytime Sleepiness

Table 1 shows demographic and clinical characteristics. There was statistical significance between the groups in terms of age, gender, education level and living status ( $\mathrm{p}$ values: 0.038, 0.034, 0.028 and 0.001, respectively). Diabetes mellitus and cerebrovascular events were statistically higher in the EDS and Insomnia group (p values: 0.002 and 0.025 , respectively); Parkinson's disease was statistically higher in EDS only group (p value: 0.001). There was a significant difference between study groups in terms of geriatric assessment parameters. In the EDS and Insomnia group, moderate and high FoF, postural instability, number of drugs and GDS scores were significantly higher, while BADL, IADL and MMSE scores were significantly lower (Table 1). In EDS only group, the falls in a year was significantly higher, while the Tinetti total score was significantly lower (p values: 0.014 and 0.036 , respectively). Logistic regression analysis was applied to all sleep disorder groups. 
Table 1: Demographic and Clinical Characteristics of the Participants (n: 661)

\begin{tabular}{|c|c|c|c|c|c|}
\hline Characteristic & $\begin{array}{c}\text { Control } \\
n=209\end{array}$ & $\begin{array}{c}\text { EDS only } \\
\quad n=36\end{array}$ & $\begin{array}{l}\text { Insomnia only } \\
\quad \mathbf{n}=333\end{array}$ & $\begin{array}{c}\text { Both (EDS and } \\
\text { Insomnia) } \\
n=83\end{array}$ & $P$ value \\
\hline Age (years) & $78.90 \pm 7.16$ & $79.86 \pm 7.40$ & $77.35 \pm 8.08$ & $80.73 \pm 7.08$ & 0.038 \\
\hline Gender, female, \% & 68.40 & 59.50 & 80.50 & 61.40 & 0.034 \\
\hline Education (years) & $5.85 \pm 4.37$ & $5.30 \pm 4.82$ & $4.47 \pm 4.45$ & $4.52 \pm 4.56$ & 0.028 \\
\hline \multicolumn{6}{|l|}{ Living Status, \% } \\
\hline Alone & 15.3 & 8.3 & 14.4 & 7.2 & \\
\hline With Spouse & 58.9 & 44.4 & 45.3 & 45.8 & \\
\hline With Family & 23.4 & 41.7 & 39.1 & 42.2 & 0.001 \\
\hline With Caregiver & 2.4 & 5.6 & 1.2 & 4.8 & \\
\hline \multicolumn{6}{|l|}{ Comorbitidies, \% } \\
\hline Hypertension & 68.4 & 78.4 & 71.0 & 74.4 & 0.55 \\
\hline Diabetes Mellitus & 27.9 & 45.9 & 39.0 & 50.0 & 0.002 \\
\hline $\begin{array}{l}\text { Ischemic } \quad \text { Heart } \\
\text { Disease }\end{array}$ & 17.5 & 29.7 & 17.7 & 25.6 & 0.13 \\
\hline COPD & 7.2 & 10.8 & 9.6 & 15.9 & 0.16 \\
\hline $\begin{array}{l}\text { Cerebrovasculer } \\
\text { Events }\end{array}$ & 10.1 & 18.9 & 10.2 & 20.7 & 0.025 \\
\hline $\begin{array}{l}\text { Congestive Heart } \\
\text { Failure }\end{array}$ & 9.2 & 0.0 & 13.2 & 12.2 & 0.074 \\
\hline $\begin{array}{ll}\text { Peripheral } & \text { Artery } \\
\text { Disease } & \end{array}$ & 2.9 & 5.4 & 2.4 & 4.9 & 0.54 \\
\hline Parkinson's Disease & 3.4 & 18.9 & 6.0 & 11.0 & 0.001 \\
\hline Osteoartiritis & 12.5 & 8.1 & 17.1 & 9.9 & 0.165 \\
\hline \multicolumn{6}{|l|}{$\begin{array}{l}\text { Geriatric } \\
\text { Assessment }\end{array}$} \\
\hline Falls in a year, $\%$ & 32.2 & 56.8 & 38.7 & 51.3 & 0.014 \\
\hline $\begin{array}{l}\text { Moderate and High } \\
\text { FoF, } \%\end{array}$ & 16.7 & 30.0 & 36.9 & 50.7 & 0.001 \\
\hline Postural instability & 16.3 & 27.0 & 20.7 & 37.3 & 0.003 \\
\hline Number of drugs & $5.20 \pm 3.19$ & $6.44 \pm 3.67$ & $6.05 \pm 3.22$ & $7.15 \pm 3.49$ & 0.022 \\
\hline BADL score & $89.81 \pm 14.21$ & $72.86 \pm 26.39$ & $81.40 \pm 20.33$ & $64.05 \pm 30.83$ & 0.035 \\
\hline IADL score & $17.37 \pm 6.10$ & $11.81 \pm 7.63$ & $15.05 \pm 6.93$ & $10.42 \pm 7.39$ & 0.041 \\
\hline Tinetti total score & $24.14 \pm 6.72$ & $17.37 \pm 9.73$ & $21.65 \pm 8.19$ & $17.63 \pm 10.45$ & 0.036 \\
\hline MMSE & $25.28 \pm 3.96$ & $23.47 \pm 5.96$ & $24.06 \pm 4.75$ & $23.55 \pm 4.88$ & 0.026 \\
\hline GDS & $3.43 \pm 3.78$ & $5.88 \pm 4.44$ & $6.64 \pm 4.42$ & $6.64 \pm 4.54$ & 0.032 \\
\hline
\end{tabular}

*BADL: Basic Activities of Daily Living; COPD: Chronic Obstructive Pulmonary Disease; EDS: Excessive Daytime Sleepiness; FoF: Fear of Falling; IADL: Instrumental Activities of Daily Living; MMSE: Mini-Mental State Examination; GDS: Geriatric Depression Scale

Table 2 shows bivariate and multivariate relationships between sleep parameters and related variables. In the logistic regression analysis performed after adjustment for age and gender, Diabetes Mellitus (OR=2.57, 95\% CI: 1.51 to 4.36), $\mathrm{COPD}(\mathrm{OR}=2.41,95 \% \mathrm{CI}$ : 1.10 to 5.32) and cerebrovascular events in the EDS and Insomnia group (OR=2.43, 95\% CI: 1.20 to 4.92 ) remained significant (p values: $0.001,0.02$ and 0.01 , respectively). In the analysis performed after adjustment for age and gender, ischemic heart disease (OR=1.98, 95\% CI: 1.03 to 3.78) in the EDS and Insomnia group was statistically significant (p value: 0.03 ). Parkinson's disease was significantly higher in the EDS only group and EDS and Insomnia group (p values: 0.001 and 0.01, respectively). Bivariate and multivariate logistic regression analysis results of geriatric assessment parameters among sleep disorders groups are shown in Table 2. 
Table 2: Bivariate and Multivariate Relationship between Sleep Parameters and Related Variables

\begin{tabular}{|c|c|c|c|c|c|c|}
\hline Variables & $\begin{array}{c}\text { EDS } \\
\text { LR (OR, 95\% } \\
\text { CI })\end{array}$ & $P$ value & $\begin{array}{c}\text { Insomnia } \\
\text { LR (OR, 95\% } \\
\text { CI })\end{array}$ & $P$ value & $\begin{array}{c}\text { EDS and } \\
\text { Insomnia } \\
\text { LR (OR, } 95 \% \\
\text { CI })\end{array}$ & $P$ value \\
\hline Age (years) & $\begin{array}{l}1.06(1.00- \\
1.12)\end{array}$ & 0.02 & $\begin{array}{c}1.00(0.98- \\
1.03)\end{array}$ & 0.50 & $\begin{array}{c}1.10(1.03- \\
1.12)\end{array}$ & 0.029 \\
\hline Gender, female & $\begin{array}{c}0.67(0.33- \\
1.38)\end{array}$ & 0.28 & $\begin{array}{l}1.91(1.28- \\
2.84)\end{array}$ & 0.001 & $\begin{array}{c}0.72(0.42- \\
1.23)\end{array}$ & 0.23 \\
\hline \multicolumn{7}{|l|}{ Comorbidities, \% } \\
\hline Hypertension & $\begin{array}{l}1.67(0.72- \\
3.85)\end{array}$ & 0.22 & $\begin{array}{c}1.12(0.77- \\
1.64)\end{array}$ & 0.53 & $\begin{array}{l}1.32(0.74- \\
2.35)\end{array}$ & 0.34 \\
\hline Diabetes Mellitus & $\begin{array}{l}2.20(1.07- \\
4.49)\end{array}$ & $0.03 *$ & $\begin{array}{l}1.66(1.13- \\
2.41)\end{array}$ & $0.008 *$ & $\begin{array}{l}2.57(1.51- \\
\quad 4.36)\end{array}$ & $0.001 *$ \\
\hline $\begin{array}{l}\text { Ischemic heart } \\
\text { disease }\end{array}$ & $\begin{array}{l}1.99(0.95- \\
4.40)\end{array}$ & 0.08 & $\begin{array}{l}1.01(0.64- \\
1.60)\end{array}$ & 0.94 & $\begin{array}{l}1.67(0.90- \\
3.10)\end{array}$ & $1.10 * *$ \\
\hline COPD & $\begin{array}{c}1.56(0.49- \\
4.99)\end{array}$ & 0.45 & $\begin{array}{l}1.36(0.71- \\
2.58)\end{array}$ & 0.34 & $\begin{array}{l}2.41(1.10- \\
5.32)\end{array}$ & $0.02 *$ \\
\hline $\begin{array}{l}\text { Cerebrovascular } \\
\text { events }\end{array}$ & $\begin{array}{l}2.06(0.80- \\
5.28)\end{array}$ & 0.12 & $\begin{array}{c}1.00(0.56- \\
1.78)\end{array}$ & 0.99 & $\begin{array}{l}2.43(1.20- \\
4.92)\end{array}$ & $0.01 *$ \\
\hline $\begin{array}{l}\text { Congestive heart } \\
\text { failure }\end{array}$ & $\begin{array}{l}0.01(0.01- \\
0.02)\end{array}$ & 0.09 & $\begin{array}{c}1.49(0.84- \\
2.63)\end{array}$ & 0.16 & $\begin{array}{c}1.44(0.63- \\
3.27)\end{array}$ & 0.38 \\
\hline $\begin{array}{l}\text { Peripheral artery } \\
\text { disease }\end{array}$ & $\begin{array}{l}1.92(0.37- \\
9.91)\end{array}$ & 0.43 & $\begin{array}{l}0.82(0.28- \\
2.41)\end{array}$ & 0.72 & $\begin{array}{l}2.07(0.54- \\
7.91)\end{array}$ & 0.28 \\
\hline Parkinson's disease & $\begin{array}{l}6.66(2.18- \\
20.34)\end{array}$ & $0.001 *$ & $\begin{array}{c}1.82(0.75- \\
4.38)\end{array}$ & 0.18 & $\begin{array}{l}3.50(1.26- \\
9.75)\end{array}$ & $0.01 *$ \\
\hline Osteoarthritis & $\begin{array}{l}0.61(0.17- \\
2.15)\end{array}$ & 0.04 & $\begin{array}{c}1.44(0.87- \\
2.37)\end{array}$ & 0.15 & $\begin{array}{l}0.76(0.33- \\
1.76)\end{array}$ & 0.52 \\
\hline \multicolumn{7}{|l|}{$\begin{array}{l}\text { Geriatric } \\
\text { Assessment }\end{array}$} \\
\hline Falls in a year & $\begin{array}{l}2.76(1.36- \\
5.63)\end{array}$ & $0.005 *$ & $\begin{array}{c}1.36(0.97- \\
1.91)\end{array}$ & 0.072 & $\begin{array}{l}2.25(1.32- \\
3.80)\end{array}$ & $0.003^{*}$ \\
\hline $\begin{array}{l}\text { Moderate and High } \\
\text { FoF }\end{array}$ & $\begin{array}{l}1.50(1.06- \\
2.12)\end{array}$ & $0.02 *$ & $\begin{array}{c}1.64(1.36- \\
1.98)\end{array}$ & $0.001 *$ & $\begin{array}{c}2.24(1.74- \\
2.89)\end{array}$ & $0.001 *$ \\
\hline Postural instability & $\begin{array}{c}1.94(0.58- \\
6.43)\end{array}$ & 0.27 & $\begin{array}{l}1.95(1.06- \\
3.61)\end{array}$ & 0.031 & $\begin{array}{c}1.65(0.63- \\
4.29)\end{array}$ & 0.30 \\
\hline Polypharmacy & $\begin{array}{c}1.11(1.00- \\
1.23)\end{array}$ & $0.04 * * *$ & $\begin{array}{c}1.08(1.03- \\
1.15)\end{array}$ & $0.004 *$ & $\begin{array}{c}1.20(1.09- \\
1.30)\end{array}$ & $0.001 *$ \\
\hline BADL score & $\begin{array}{c}0.96(0.94- \\
0.98)\end{array}$ & $0.001 *$ & $\begin{array}{c}0.97(0.95- \\
0.98)\end{array}$ & $0.001 *$ & $\begin{array}{c}0.94(0.93- \\
0.96)\end{array}$ & $0.001 *$ \\
\hline IADL score & $\begin{array}{c}0.89(0.84- \\
0.93)\end{array}$ & $0.001 *$ & $\begin{array}{c}0.95(0.92- \\
0.97)\end{array}$ & $0.001 *$ & $\begin{array}{c}0.87(0.84- \\
0.91)\end{array}$ & $0.001 *$ \\
\hline Tinetti total score & $\begin{array}{c}0.91(0.87- \\
0.95)\end{array}$ & $0.001 *$ & $\begin{array}{c}0.95(0.31- \\
0.98)\end{array}$ & $0.001 *$ & $\begin{array}{c}0.92(0.89- \\
0.95)\end{array}$ & $0.001 *$ \\
\hline MMSE & $\begin{array}{c}0.92(0.85- \\
0.99)\end{array}$ & $0.040 * * *$ & $\begin{array}{c}0.93(0.89- \\
0.97)\end{array}$ & $0.04 * * *$ & $\begin{array}{c}0.91(0.86- \\
0.98)\end{array}$ & $0.007 *$ \\
\hline GDS & $\begin{array}{c}1.14(1.05- \\
1.24)\end{array}$ & $0.002 *$ & $\begin{array}{c}1.21(1.15- \\
1.27)\end{array}$ & $0.001 *$ & $\begin{array}{l}1.19(1.11- \\
1.27)\end{array}$ & $0.001 *$ \\
\hline
\end{tabular}

BADL: Basic Activities of Daily Living; COPD: Chronic Obstructive Pulmonary Disease; EDS: Excessive Daytime Sleepiness; FoF: Fear of Falling; GDS: Geriatric Depression Scale; IADL: Instrumental Activities of Daily Living; MMSE: Mini-Mental State Examination

* States that statistical significance continues after adjustment for age and gender. ** States that ischemic heart disease becomes statistically significant after adjustment for age and gender [OR=1.98, \%95 CI: 1.03 to 3.78), p value 0.03]. *** States that statistical significance disappeared after adjustment for age and gender

\section{Discussion}

Our study is the first to evaluate the risk factors of EDS and insomnia, and the effects of these two sleep disorders on functionality, gait-balance functions, cognition and mood both separately and together in the elderly. In our study, it was determined that the frequency of EDS and insomnia increased in the presence of chronic diseases such as diabetes 
mellitus, ischemic heart disease, COPD and cerebrovascular disease, regardless of age and gender. However, it was determined that EDS and insomnia, both separately and in combination, continued to have significant negative effects on functionality, gait-balance functions, cognition and mood. Therefore, the association of EDS and insomnia is important in geriatric nursing practice.

It is known that insomnia symptoms increase with advancing age and the prevalence is approximately $50 \%$ in individuals aged 65 and over (23). In our study, the prevalence of sleep disorders (only insomnia, only EDS and insomnia and EDS) was found to be $68.39 \%$, which means that 2 out of every 3 elderly patients suffer from sleep disorders. For this reason, sleep problems in elderly patients should be considered as an important and common health problem. In addition, it was determined that complaints of sleep disorders were more common in elderly female patients than male. At the same time, insomnia was 1.91 times higher in females. There are studies reporting different results regarding the relationship between sleep problems and gender. Oliveira et al. (24) concluded that insomnia symptoms are more common in elderly females, while another study reported that female gender was not an independent risk factor for sleep disorders (25). These differences may result from the methodological discrepancies of the studies as well as the fact that some hormonal and biological ones in both genders may affect sleep disorders (26).

Studies examining the prevalence of sleep disorders in elderly patients with chronic medical diseases have reported that most diabetics have difficulty falling asleep and/or maintaining sleep and that those with congestive heart failure, cancer, dyspnea due to chronic obstructive pulmonary disease, cerebrovascular diseases and Parkinson's disease are more likely to have sleep complaints $(27,28)$. In our study, a close relationship was shown between some comorbid diseases and sleep disorders. For example, in the presence of diabetes mellitus, regardless of age and gender, the risk of EDS increased by 2.2, insomnia 1.6, and the risk of co-occurrence of insomnia and EDS was 2.5 times. There may be a bidirectional relationship between diabetes mellitus and sleep disorders. Sleep disturbances may increase the risk of type 2 diabetes mellitus by leading to changes in insulin sensitivity and glucose metabolism (29, 30). Complications associated with type 2 diabetes mellitus (such as pain and nocturia) are also known to adversely affect sleep quality and duration (31). In the study, the risk of EDS increased 6.6 times and the risk of insomnia and EDS increased 3.5 times in the elderly with Parkinson's disease. Sleep disturbances, which are common in patients with Parkinson's, ,are considered to be present in the early stages of the disease (32). In a 5-year prospective study in patients with Parkinson's disease, the rates of insomnia were $12.8 \%$, EDS $8.3 \%$, and insomnia and EDS $2.3 \%$ at the onset of the disease, whereas the rates of insomnia, EDS, and insomnia EDS were 19\%, 8.7\%, and 10.6\%, respectively, after a 5-year follow-up (33). In another study, it was reported that EDS is 35\% in patients with Parkinson's disease (34). In our study, the risk of co-occurrence of insomnia and EDS increased by 1.67, 2.4 and 2.4 times, respectively, in patients with ischemic heart disease, COPD and cerebrovascular disease. Consistent with our results, it has been shown that heart disease, stroke, and lung diseases are independently associated with sleep problems such as insomnia and EDS in elderly patients (27). The relationship between all these chronic diseases and sleep disorders may be directly or indirectly in a two-way relationship. Therefore, elderly patients with comorbidities such as diabetes mellitus, Parkinson's disease, ischemic heart disease, COPD and cerebrovascular disease should be evaluated in detail in terms of sleep problems, and elderly patients with sleep problems such as insomnia and/or EDS should be evaluated in detail for these comorbidities.

Falls, FoF and gait-balance problems that are common in the elderly, can cause serious health problems (35, 36). According to the results of our study, insomnia and/or EDS significantly increased falls and FoF. The risk of falling could be associated with a significantly lower Tinetti total score. Indeed, previous study results evaluating insomnia and EDS separately support our results $(35,36)$. However, for the first time, this study revealed that the rate of FoF was much higher in patients with both EDS and insomnia. Therefore, it is important to evaluate these two interrelated sleep disorders together in elderly care practice.

It is known that polypharmacy may contribute to an increased risk of sleep disorders in older adults (23). In our study, there was no significant relationship between polypharmacy and EDS, but there was a significant relationship between polypharmacy and insomnia and insomnia and EDS. Polypharmacy is becoming increasingly common among older adults. In most cases, the effect of drugs on patients' sleep patterns is not taken into account. Most medications prescribed for chronic medical and psychiatric conditions, central nervous system stimulants (eg modafinil, methylphenidate), antihypertensives (eg $\beta$-blockers, $\alpha$-blockers), respiratory diseases can cause or exacerbate insomnia (28). Therefore, psychostimulant drugs and diuretics should be taken early in the day, while sedatives should be administered before going to bed at night.

Sleep state has an extremely important effect on maintaining optimal cognitive functioning (39). In a sample of 1.844 elderly women, patients who had difficulty falling or staying asleep or who slept less than 5 hours a night showed worse cognitive performance than the control group at 2-year follow-up evaluations (40). According to our results, there was no significant decrease in MMSE scores in patients with only insomnia and only EDS, while a significant decrease was found in MMSE scores in the association of insomnia and EDS. Previous studies have shown that insomnia is a significant risk for depression (41); however, it may be remarked that this is a two-way relationship because mood also affects sleep quality. Being angry, anxious, or depressed leads to poor sleep quality. Such negative emotions have been shown to be associated with decline in cognitive functions (42). In our study, a significant correlation was determined with depressive symptoms in all sleep disorder groups. In a recent study, it was reported that sleep disorders were significantly associated with cognition and mood in elderly patients (43). For this reason, early recognition and good management of depression may contribute to improvement in sleep patterns and, consequently, improvement in cognitive functions. Because of the multitude of effects of sleep disorders that can cause disability (such as cognition, falling, fear of falling, depression, diabetes mellitus, Parkinson's disease), it is not surprising that sleep disorders have been indicated to be associated with worsening activities of daily living (BADL and IADL).

The strengths of our study are: sufficient sample size, performing comprehensive geriatric assessment in all 
patients, and evaluation of comorbid diseases. To the best of our knowledge, our study is the first to evaluate the effects of insomnia and EDS on functionality, gait-balance functions, cognition and mood both separately and together in the elderly.

Aging is associated with numerous changes, including changes in sleep timing, duration, and quality. The circadian rhythm interacts with the sleep-wake homeostatic system to regulate human sleep, including sleep timing and structure (44). In the case of insomnia, the homeostatic system increases the amount of sleep we need, while the circadian system optimizes the best timing for sleep (45). This situation shows the importance of healthy circadian rhythm in elderly individuals.

\section{Limitations}

There were few limitations to this study. It was performed only in one region of Turkey, using convenience sample methods. Therefore, the results of this study can only be generalized to the studied sample. Only the ESS scale was used for EDS; hence, future studies should consider using objective measures of sleep to diagnose daytime sleepiness, such as actigraphy.

\section{Use of Results in Practice}

Sleep disorders are common in elderly patients and EDS and insomnia is common in diabetes mellitus, COPD, coronary artery disease and cerebrovascular diseases, and EDS is common in Parkinson's patients. The association of EDS, insomnia and EDS and insomnia is closely and significantly associated with negative health outcomes such as falls, gait-balance disorder, FoF, depressed mood, and impaired functionality. Therefore, elderly patients with the mentioned comorbidities followed in inpatient services should be carefully evaluated for the presence of sleep disorders. Although insomnia and/or EDS are not expressed as complaints by the elderly, they may be detected early within the scope of nursing service. Potential negative health consequences on the functionality, cognition, mood and gait-balance functions of the elderly individual may be prevented early and effectively by early interventions to ensure a healthy circadian rhythm. It is well known as the aging population will need more health services, it is inevitable that the use of medical and social services will increase further in the future. Insomnia and/or EDS in elderly patients has a close relationship between FoF, polypharmacy, activities of daily living and cognition, and these variables is important for elderly care in nursing. Our study is important in terms of increasing the awareness among nurses about the effects of insomnia and/or EDS in elderly patients. In addition to this, the present study can also be beneficial to many professional groups that will work in the field of health to serve the elderly.

\section{Acknowledgement}

Ethics in Research Committee of the local ethics committees approved this study (Approval number: 2019/362, Date: 8.5.2019). All authors contributed to the study conception and design. All authors read and approved the final manuscript. SKO: study design, data collection, statistics, results interpretation, writing the manuscript, PS: study design, data collection, statistics, results interpretation, writing the manuscript LS: study design, statistics, results interpretation, critical review, BAS: study design, results interpretation, critical review, MAA: study design, results interpretation, critical review. 


\section{References}

1. Yaremchuk K. Sleep disorders in the elderly. Clin Geriatr Med 2018;34(2):205-216.

2. Littner MR, Kushida C, Wise M, Davila DG, Morgenthaler T, Lee-Chiong T, et al. Practice parameters for clinical use of the multiple sleep latency test and the maintenance of wakefulness test. Sleep 2005;28(1):113-121.

3. Chasens ER, Williams LL UM. Excessive sleepiness. In: Capezuti E, Zwicker D MM, editor. Evidence-based geriatric nursing protocols for best practice. 3rd ed. New York: Springer: Publishing Company; 2008. p. 459-76.

4. Simonson W, Bergeron CA, Crecelius CA, Murphy R, Roth Maguire S, Osterweil D, Clinical Professor C, et al. Improving sleep management in the elderly. [online] 2007;1-17. URL: http://citeseerx.ist.psu.edu/viewdoc/download?doi=10.1.1.468.1446\&rep=rep1\&type=pdf. 10.07.2021.

5. Flores S. Sleepiness or excessive daytime somnolence. Geriatr Nurs 2009;30(1):53-60.

6. Gulia KK, Kumar VM. Sleep disorders in the elderly: A growing challenge. Psychogeriatrics 2018;18(3),155-165.

7. Lopes JM, Dantas FG, Medeiros JLA de. Excessive daytime sleepiness in the elderly: Association with cardiovascular risk, obesity and depression. Rev Bras Epidemiol 2013;16:872-879.

8. Gooneratne NS, Weaver TE, Cater JR, Pack FM, Arner HM, Greenberg AS, et al. Functional outcomes of excessive daytime sleepiness in older adults. J Am Geriatr Soc 2003;51(5):642-649.

9. Luck KE, Doucet S. A rapid review exploring nurse-led memory clinics. Nursing Open 2021;8:1538-1549.

10. Mozo-Alonso F, Novalbos-Ruiz JP, Duran-Alonso JC, Rodríguez-Martin A. Nutritional status of noninstitutionalized adults aged over 65. Study of weight and health in older adults (PYSMA). Nutrients 2021;13(5),1561.

11. Chidume T. Promoting older adult fall prevention education and awareness in a community setting: A nurse-led intervention. Appl Nurs Res 2021;57:151392.

12. Kulakci Altintas H, Korkmaz Aslan G. Incidence of falls among community-dwelling older adults in Turkey and its relationship with pain and insomnia. Int J Nurs Pract 2019;25(5):e12766.

13. Piamjariyakul U, Shapiro AL, Wang K, Zulfikar R, Petitte T, Shafique S, et al. Impact of Sleep Apnea, Daytime Sleepiness, Comorbidities, and Depression on Patients' Heart Failure Health Status. Clin Nurs Res 2021:1-9.

14. Unutmaz GD, Soysal P, Tuven B, Isik AT. Costs of medication in older patients: Before and after comprehensive geriatric assessment. Clin Interv Aging 2018;13:607-613.

15. Ates Bulut E, Soysal P, Isik AT. Frequency and coincidence of geriatric syndromes according to age groups: Single-center experience in Turkey between 2013 and 2017. Clin Interv Aging 2018;13:1899-905.

16. Delbaere K, Smith ST, Lord SR. Development and initial validation of the Iconographical Falls Efficacy Scale. J Gerontol A Biol Sci Med Sci 2011 Jun;66(6):674-680.

17. Rivasi G, Kenny RA, Ungar A, Romero-Ortuno R. Predictors of Incident Fear of Falling in Community-Dwelling Older Adults. J Am Med Dir Assoc 2019;21(5):615-620.

18. Bloem BR, Marinus J, Almeida Q, Dibble L, Nieuwboer A, Post B, et al. Measurement instruments to assess posture, gait, and balance in Parkinson's disease: Critique and recommendations. Movement Disorders 2016;31(9):1342-1355.

19. Durmaz B, Soysal P, Ellidokuz H, Isik AT. Validity and reliability of geriatric depression scale-15 (Short Form) in Turkish older adults. North Clin Istanbul 2018;5(3):216-220.

20. Morin CM, Belleville G, Bélanger L, Ivers H. The insomnia severity index: Psychometric indicators to detect insomnia cases and evaluate treatment response. Sleep 34(5):601-608.

21. Bastien CH, Vallières A, Morin CM. Validation of the insomnia severity index as an outcome measure for insomnia research. Sleep Med 2001;2(4):297-307.

22. Johns MW. Sensitivity and specificity of the multiple sleep latency test (MSLT), the maintenance of wakefulness test and the Epworth sleepiness scale: Failure of the MSLT as a gold standard. J Sleep Res 2000;9(1):5-11.

23. Miner B, Kryger MH. Sleep in the Aging Population. Sleep Med Clin. 2020;15(2):311-318.

24. Oliveira BHD, Yassuda MS, Cupertino APFB, Neri AL. Relations between sleep patterns, perceived health and socioeconomic variables in a sample of community resident elders - PENSA Study. Ciencia e Saude Coletiva 2010;15(3):851-860.

25. Su TP, Huang SR, Chou P. Prevalence and risk factors of insomnia in community-dwelling chinese elderly: A Taiwanese urban area survey. Aust New Zeal J Psychiatry 2004;38(9):706-713.

26. Honig E, Green A, Dagan Y. Gender differences in the sleep variables contributing to excessive daytime sleepiness among patients with obstructive sleep apnea. Sleep Breath 2021:1-6.

27. Foley D, Ancoli-Israel S, Britz P, Walsh J. Sleep disturbances and chronic disease in older adults: Results of the 2003 National Sleep Foundation Sleep in America Survey. J Psychosom Res 2004;56(5):497-502.

28. Neikrug AB, Ancoli-Israel S. Sleep disorders in the older adult-A mini-review. Gerontology 2010;56(2):181-189.

29. Spiegel K, Knutson K, Leproult R, Tasali E, Van Cauter E. Sleep loss: A novel risk factor for insulin resistance and Type 2 diabetes. J Appl Physiol 2006;99(5):2008-2019.

30. Strand LB, Carnethon M, Biggs M Lou, E LD, Kaplan RC, Siscovick DS, et al. Sleep disturbances and glucose metabolism in older adults: The cardiovascular health study. Diabetes Care 2015;38(11):2050-2058.

31. Holingue C, Wennberg A, Berger S, Polotsky VY, Spira AP. Disturbed sleep and diabetes: A potential nexus of dementia risk. Metabolism 2018;84:85-93.

32. Bargiotas P, Schuepbach MWM, Bassetti CL. Sleep-wake disturbances in the premotor and early stage of Parkinson's disease. Curr Opin Neurol 2016;29(6):763-772.

33. Xu Z, Anderson KN, Saffari SE, Lawson RA, Chaudhuri KR, Brooks D, et al. Progression of sleep disturbances in Parkinson's disease: A 5-year longitudinal study. J Neurol 2021;268(1):312-320. 
34. Feng F, Cai YY, Hou YB, Ou R, Jiang Z, Shang HF. Excessive daytime sleepiness in Parkinson's disease: A systematic review and meta-analysis. Parkinsonism Relat Disord 2021;85:133-140.

35. Dokuzlar O, Koc Okudur S, Soysal P, Kocyigit SE, Yavuz I, Smith L, et al. Factors that Increase Risk of Falling in Older Men according to Four Different Clinical Methods. Exp Aging Res. 2020;46(1):83-92.

36. Dokuzlar O, Koc Okudur S, Smith L, Soysal P, Yavuz I, Aydin AE, et al. Assessment of factors that increase risk of falling in older women by four different clinical methods. Aging Clin Exp Res 2020;32(3):483-490.

37. Soysal P, Smith L, Tan SG, Capar E, Veronese N, Yang L. Excessive daytime sleepiness is associated with an increased frequency of falls and sarcopenia. Exp Gerontol 2021;150:111364.

38. Unsal P, Sengul Aycicek G, Deniz O, Esme M, Dikmeer A, Balc1 C, et al. Insomnia and falls in older adults: Are they linked to executive dysfunction? Psychogeriatrics 2021;21(3):359-367.

39. Malhotra RK, Desai AK. Healthy brain aging: What has sleep got to do with it? Clin Geriatr Med 2010;26(1):4556.

40. Tworoger SS, Lee S, Schernhammer ES, Grodstein F. The association of self-reported sleep duration, difficulty sleeping, and snoring with cognitive function in older women. Alzheimer Dis Assoc Disord 2006;20(1):41-48.

41. Nutt DJ, Wilson S, Paterson L. Sleep disorders as core symptoms of depression. Dialogues Clin Neurosci 2008;10(3):329-336.

42. Vance DE, Heaton K, Eaves Y, Fazeli PL. Sleep and cognition on everyday functioning in older adults: Implications for nursing practice and research. J Neurosci Nurs 2011;43(5):261-271.

43. Jiang HX, Xie X, Xu Y, Wang R, Lei X, Yu J. Older Adults' Subjective Cognitive Decline Correlated with Subjective but Not Objective Sleep: A Mediator Role of Depression. Int J Aging Hum Dev 2021;1-15.

44. Suzuki K, Miyamoto M, Hirata K. Sleep disorders in the elderly: Diagnosis and management. J Gen Fam Med 2017;18(2):61-71.

45. Neubauer DN. A review of ramelteon in the treatment of sleep disorders. Neuropsychiatr Dis Treat 2008;4(1):6979 . 